\title{
The Difference of Students' Mathematical Communication Ability Taught by Cooperative Learning Model Think Talk Write Type and Numbered Head Together Type
}

\author{
Meiva Marthaulina Lestari Siahaan, E. Elvis Napitupulu \\ meiva.lestari@uph.edu, elvisnapit@gmail.com \\ Universitas Pelita Harapan, Universitas Negeri Medan
}

\begin{abstract}
The purpose of this research was to know there was any difference in student's mathematical communication ability in cooperative learning Think TalkWrite (TTW) type and Numbered Head Together (NHT) type. The population was all students at SMP Negeri 1 Lubuk Pakam. The sample was two classes which each consist of 36 students, VII A as experimental class I which taught by TTW and VII B as experimental class II which taught by NHT. The sample was taken by cluster random sampling. Collecting data technique of this research was mathematical comunication ability essay test that was given in the end of learning either in experimental class I or experimental class II. From the data analysis of each of experimental class were obtained that the average of posttest score in TTW classroom was higher than in NHT classroom. It was also obtained that score of mathematical communication indicators in TTW classroom was higher than in NHT classroom. From the data analysis of posttest score by using t-test with significance level $\alpha=0.05$, it was obtained that $t_{\text {count }}=4.687$ and $t_{\text {table }}=1.667$. It means that $t_{\text {count }}>t_{\text {table }}$ then $\mathrm{HO}$ was rejected and Ha was accepted. So, it can be concluded that there was difference of student's mathematical communication ability who taught by cooperative learning model type TTW with NHT at SMP Negeri 1 Lubuk Pakam.
\end{abstract}

Keywords: Students' mathematical communication, cooperative learning model NHT type, TTW type

Received date: 16 Mei 2018

Article Info

Revised date: 14 Agustus 2018 Accepted date: 21 September 2018

\section{INTRODUCTION}

Mathematics has the structural concept and relationship using symbols (Uno, 2011: 130). The symbols are very important in helping to handle the rules that operate within the structures. Symbolization also provides communication facilities so as to enable to get some information and this information can be formed from the new concept. Thus, symbols are very useful to simplify mathematical thinking as this symbol can be used to communicate an ideas.

We can say that the essence of mathematics and mathematical thinking relates to idea, structure, and information in symbol form and to bulid these, we need mathematical communication to facilitate it. So, student's ability in communicating is important in mathematics learning. Baroody (Ansari, 2012 : 4) explains there are at least two important reasons why communication in mathematics needs to grow. First, mathematics as language, it means that mathematics is not only a tool to aid thinking, to find pattern, to solve problem and to take conclusion but also valuable tool to communicate various ideas clearly and exactly. Second, mathematics learning as social activity, it means that mathematics is a place for interactions and communication between students and teacher.

Students need to be able to analyze the problem, find an appropriate method for solving, and then communicate those steps with the teacher or their peers (Wichelt, 2009 : 2). Mathematical communication is needed by students to understand the mathematical ideas correctly. Likewise, students who already have mathematical understanding are also required to be able to communicate their understanding, so that understanding can be understood by others. By communicating mathematical ideas to others, a student can enhance mathematical understanding. Huggins (In Qohar, 2011 : 2) suggested that in order to improve mathematical conceptual understanding, students can 
The Difference of Students' Mathematical Communication Ability Taught by Cooperative Learning Model Think Talk Write Type and ... (Meiva Marthaulina Lestari Siahaan, E. Elvis Napitupulu)

communicate mathematical ideas to others. There are some points of concern on mathematical communication, that are:(1) the ability of stating mathematical problems into mathematical models, (2) the ability of explaining mathematical problems into figures, and (3) the ability of explaining problem situations by own words and doing calculations.

Based on preliminary study of students in grade VII at SMP Negeri 1 Lubuk Pakam, the students are not able to make algebra equations when asked to write the equation to solve the problem. The problem number one is: Vera's age is 4 years lesser than Togar's age. If the combined amount of their age is 24 years old, determine the each of their ages.

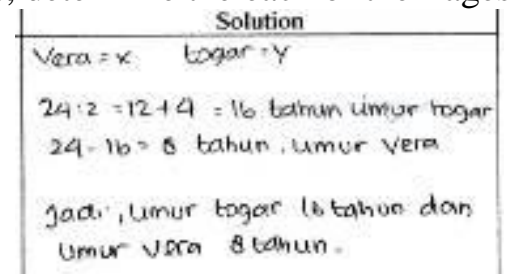

Figure 1.

Student's answer for The First Problem

The indicator of mathematical communication ability in problem number one is that students are able to state problem in writing into mathematical model (Ansari, 2012 : 10). From the above, figure 1 shows that they can not make the equation of Vera's age is 4 years lesser than Togar's age. It means the student's ability in stating problem by writing into mathematical models is low.

The problem number two is: A farmer has land in the shape of rectangle. The width is $6 \mathrm{~m}$ shorter than the length. If the perimeter is $60 \mathrm{~m}$, determine the area of land.

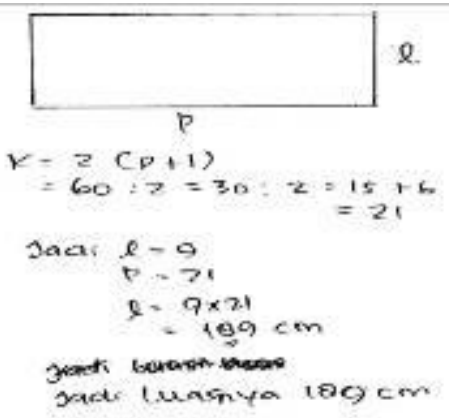

Figure 2.

\section{Student's answer for The Second Problem}

Indicators of mathematical communication ability in problem number two are explaining problem in writing by using a figure and stating problem in writing into mathematical models (Ansari, 2012 : 10). Figure 2 shows that they can not change length and width into variables and automatically they can not draw given condition, based on the problems, into figure. It means student's ability in explaining problem in writing into a figure is also weak.

The third problem is : State this following picture in fractional form and in your own word!

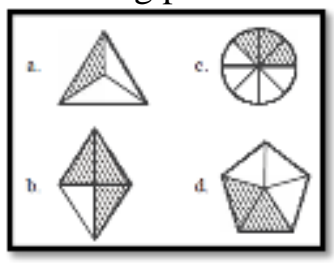

Figure 3.

The Third Problem of Observation Test 
A student's answer is shown picture below.

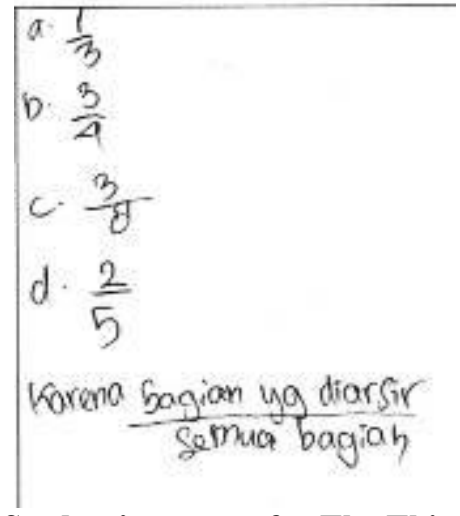

Figure 4. Student's answer for The Third Problem

The indicators of mathematical communication ability in problem number three are explaining problem situations in own words and doing calculations (Ansari, 2012 : 10). Figure 4 shows that the student can not communicating ideas or situations exactly of the meaning of shaded and non-shaded areas in the picture or in mathematical notation, in fractional form, what denominator and numenator is. It means the student's ability to explain problem situations in own words and doing calculations is also weak.

Refering to this preliminary study, it can be concluded that the student's mathematical communication ability is still inadequate and unsatisfactory. This happened due to lack of their understanding of algebra and systems of linear equations of two variables as well as their lack of mathematical communication skills because they are not accustomed to change abstract models to real preformance form of mathematical models.

According to the constructivist learning theory, knowledge can not simply be transferred from the teacher to the mind of the student. This means that students must be mentally active to build knowledge based on student's cognitive maturity structure. An acitivity which can be applied for making active learning also for developing student's mathematical communication ability is to implement TTW type and NHT type. One of the benefits of cooperative learning is the sharing process among students. Sharing can be a form of brainstorming, advice groups, cooperation in groups, group presentations, and feedback from teachers so as to improve their ability to communicate their thoughts both orally and in writing.

Brenner (In Qohar, 2011 : 6) found that the formation of small groups facilitate the development of mathematical communication skills. Given the small groups, then the intensity of one student in expressing their opinions will be higher. This will provide a great opportunity for students to develop mathematical communication skills. This statement is strengthened by Hiebert et al (In Hillen, $2006: 4$ ) doing mathematics is a collaborative activity that depends on communication and social interaction.

Activities that expected are able to increase student's mathematical understanding and communication is applying the Think Talk Write approach, and giving open-ended task. The essence of TTW approach is giving priority to communicate or to explain results of student's mathematical thinking toward open-ended task which is given by teacher, whereas the essence of open-ended task is giving priority for process rather than result and explaining the reason of processing (Ansari, 2012 : 6). Thus, TTW is expected to improve student's mathematical communication through mathematical understanding which is stimulated by open - ended tasks.

According to Nur (In Ishabu, $2013: 68$ ), NHT is basically a variation of group discussions with a trademark to appoint a teacher of students who will represent the group without telling, in advance, who will represent the group. This method ensures the involvement of all students. This method is an excellent attempt to increase personal responsibility in group discussions. Learning in NHT provides the opportunity for students to formulate a problem first and then seek a solution by communicating student's within the group. Thus, NHT is an alternative helps students' mathematical communication ability yet it helps teachers to check student's understanding toward subject contents. 
The Difference of Students' Mathematical Communication Ability Taught by Cooperative Learning Model Think Talk Write Type and ... (Meiva Marthaulina Lestari Siahaan, E. Elvis Napitupulu)

\section{LITERATURE REVIEW}

\section{Mathematical Communication Ability}

Mathematics is the language of symbols in which every person who learns mathematics required to have the ability to communicate using the language of symbols. Hudojo (2005: 65) states that mathematics as a language of symbols which gives communical facility. It means symbols have benefit for intellectual efficiency since these are used to communicate ideas effectively and efficiently

Communication is derived from the greek word communis which means "same". Communication suggests that thinking, meaning, and message are shared. Based on the definition above everything which can give same interpretation toward a situation or problem can be said as communication. Generally, communication can be meant as an event of receiving message in one person to another in community. According to Abdulhak (In Ansari, 2012: 8), communication is a process of delivering message from sender to receiver through certain channels and a certain purpose.

Quality of interpretation or response is often a special problem in using mathematical language as communication. It is caused by mathematical characteristics which is full of terminology or symbols. Communication ability in mathematics is essential. Communication ability in mathematics is communication which enclose various changes for communicating in form: reflecting real things, image, or mathematical ideas, making situational model or problem using oral, written, concrete, graphical and algebraic method, using reading, writing, and skill of interpreting and evaluating ideas, symbol, terms, and mathematical information, also responsing problem in convinced argument (Qohar, $2011: 2$ ).

Communication is not just vital for the mathematics classroom, but in all classrooms. All educators know the importance of being able to communicate with students, to have students communicate with one another, and to have students understand what they are communicating. According to Kabasakalian (In Wichlet, 2009 : 6), the need for meaningful classroom discourse is now universally accepted among educational researchers, and teachers are encouraged to use 'higher order' questions. Both oral and written communications are key skills for all student. Educators have to be willing to push students to become good communicators.

Ansari (2012 : 9) explains that mathematical communication which will be developed is convergence communication since it contains cooperative characteristic where if there is problem or difficultness then it will be solved together in students' environment so that it can make understanding among students and the expectation is problem solving. Communication in mathematics has a close relationship between mathematical understanding and student's communication skill. Evaluation standard to measure it can be seen from: (1) stating mathematical idea by talking, writing, demonstrating, and drawing into visual form, (2) understanding, interpreting, and assesing mathematical idea which available in writing, oral, or visual form, and (3) using mathematical language, notation or structure to state idea, to draw relationships, and to make models.

NCTM (2000) formulates four standard of mathematical communication of pre-Kindergarden until class 12, they are: (1) to manage and to consolidate their mathematical thinking through communication, (2) to communicate mathematical thinking clearly to classmate, teacher, and others, (3) to analyze and to evaluate cognitions and mathematical strategy, and (4) to use mathematical language for expressing mathematical idea precisely. NCTM (1989) further explains that mathematical communication ability towards mathematical learning can be seen from: (1) ability of expressing oral and written mathematical idea and to demonstrate also to draw it visually, (2) ability of understanding, interpreting, and evaluating oral, writing and another visuual form mathematical ideas, (3) ability of using terms, mathematical notations and structure for presenting ideas, to draw connection and situational model.

Based on explanation above, the indicator of student's mathematical communication ability which will be measured are:

a. The ability of stating mathematical problem into mathematical model.

b. The ability of explaining mathematical problem into figure.

c. The ability of explaining problem situations by own words and doing calculation. 


\section{The Aspects of Communication}

According to Baroody (In Ansari, 2012 : 11), there are five aspects of communication. They are representing, listening, reading, discussing, and writing.

a. Representing

Representing are (1) new form as translation result from problem or idea, (2) translation of diagram or physical model into symbol or words (NCTM, 1989). For example, representing of multiplication form into some concrete model and representing of diagram into symbol or words. Representing can help students to explain concept or idea and making students easy to get solving strategy. In addition, the use of representing can improve flexibility in answering mathematical problem.

b. Listening

Listening is an important aspect in discussing. The students are not able to give comment well if they can not able to take essence of discussing topic. Students learn to listen more carefully when there is a question or comment from their friends. Baroody (In Ansari, 2012 : 14) states that listening carefully to friend's question in one group also can help students to construct mathematical knowledge completely and to manage strategies more effectively.

c. Reading

Reading is an activity to read text actively and to find solution of arranged questions. Actived reading also means reading which is focused in given paragraph which is estimated contains relevant answer with the question.

d. Discussing

Discussing is facility for expressing and reflecting student's thinking. Baroody (Ansari, 2012 : 15) states that discussing an idea is a good way for students who experience far gap away, unconsistency, or success of thinking purity. Discussing can give benefit for listeners because it gives new knowledge for them.

e. Writing

Writing is an activity which is done for expressing and reflecting thinking. It also be beneficial instrument of thinking since student achieves mathematical experience as creative activity.

\section{The factors of Mathematical Communication}

There are some factors which relates with mathematical communication ability, they are prior knowledge, reading, discussing, and writing ability, and mathematical knowledge.

a. Prior Knowledge

Prior knowledge is knowledge which is owned by student as result of previous learning process. Kind of ability which owned by students is very determined the next learning result. But, in mathematical communication, sometimes student's prior knowledge can not be standard to estimate oral and writing communication ability.

b. Reading, Discussing, and Writing Ability

There is a relationship among reading, discussing, and writing. A student who often reads but seldom writes will have incomplete understanding. Otherwise, if a student likes to write but does not like to read then comprehension is lacking. The best is if a student likes reading, discussing, and expressing it in writing then gathering writing result. Thus, discussing and writing are two important aspects for every level (NCTM, 1989). Meanwhile, reading ability at certain topic, elaborating the topic, and making conclusion are important aspects for success of students' thinking.

c. Mathematical Knowledge

According to Bloom (Ansari, 2012 : 27), knowledge is classified into translation, interpretation, and extrapolation knowledge. Translation knowledge is ability to understand an idea which is stated another way than the original statement. Interpretation knowedge is ability to understand or to interpret a changed idea or arranged in other form, like equality, graph, table, diagram, etc. Extrapolation knowledge is a skill to estimate continuity of certain data. 
The Difference of Students' Mathematical Communication Ability Taught by Cooperative Learning Model Think Talk Write Type and ... (Meiva Marthaulina Lestari Siahaan, E. Elvis Napitupulu)

\section{Cooperative Learning Model Think Talk Write Type}

Ansari (2012: 78) states that a strategy that is expected to grow mathematical communication skills is the strategy Think-Talk-Write (TTW). Strategy introduced by Huinker \& Laughlin (Ansari, 2012: 80) this is basically built through think, talk, and write. TTW strategy groove starting from the student's involvement in thinking or dialoguing with himself after the reading, then speak and share ideas with friends before writing. TTW involves three important stages that must be developed and conducted in the learning of mathematics. In this stage, students individually think of possible answers (solving strategies) and make a note of what have read in their own language. The next stage is to communicate by using words and language they understand (talk). In this stage allows students to skillfully speak or express ideas. Discussion or dialogue in a group of 3-5 students to improve comprehension. This activity can help solve math problems because students are given the opportunity to discuss the solution of mathematical problem solving. Stage write is write down the results of discussions on the worksheets provided SAS (Student Activity Sheet). Writing activity will help students in making inferences. As for the teacher to see how to solve a math problem step solutions and conclude the answer.

\section{Cooperative Learning Model Numbered Head Together Type}

Number Heads Together is the approach developed by Spencer Kagan in 1998 to involve more students in a review of a range of material covered in a lesson and to check their understanding of the lesson content. In other words, this type of cooperative learning is designed to influence students' interaction patterns. The first phase of NHT is numbering, every student in each group to have their own number. The second is questioning, the teacher gives a question to the students. The question is various it means specific question and interogative sentence form, and then "heads together" phase, the students communicate their own solution or step to get the solution to the group, make a conclusion and make sure that everyone understand it (Arends, 2008: 16).

\section{METHOD}

The research type was a quasi experiment. The population in this research was students at SMP Negeri 1 Lubuk Pakam. The sample, was taken by clustered - random sampling, of students in class VII A as experimental class I taught by TTW type and VII B as experimental class II taught by NHT type which each of the class consist of 36 students.

The instrument used in this study was an essay test that each of the problem had a determined indicator of mathematical communication ability. It was held after giving treatment. The test used was in the form of a description of 5 questions, in which the correction of content in this case was first done using the validity and reliability test. The table below represent that higher the score then the better the student's mathematical communication ability.

Table 1.

Scoring Guideline of Mathematical Communication Ability Test

\begin{tabular}{|c|c|c|c|}
\hline Aspect & Criteria & Score & $\begin{array}{c}\text { Question } \\
\text { No. }\end{array}$ \\
\hline $\begin{array}{l}\text { The ability of stating } \\
\text { mathematical problem } \\
\text { into mathematical model. }\end{array}$ & $\begin{array}{l}\text { - Do not make mathematical model } \\
\text { - Make mathematical model but not right nor complete } \\
\text { - Make mathematical model right but less complete } \\
\text { - Make mathematical model right and complete }\end{array}$ & $\begin{array}{l}0 \\
1 \\
2 \\
3\end{array}$ & 2 \\
\hline $\begin{array}{l}\text { The ability of explaining } \\
\text { mathematical problem } \\
\text { into figure. }\end{array}$ & $\begin{array}{l}\text { - Do not create figure } \\
\text { - Create figure but not right nor complete } \\
\text { - Create figure right but less complete } \\
\text { - Create figure right and complete }\end{array}$ & $\begin{array}{l}0 \\
1 \\
2 \\
3\end{array}$ & $1 \mathrm{a}, 1 \mathrm{~b}$ \\
\hline $\begin{array}{l}\text { The ability of explaining } \\
\text { problem situations by } \\
\text { own words and doing } \\
\text { calculation. }\end{array}$ & $\begin{array}{l}\text { - Do not explain mathematical model } \\
\text { - Explain mathematical model but not right nor complete } \\
\text { - Explain mathematical model right but less complete } \\
\text { - Explain mathematical model right and complete }\end{array}$ & $\begin{array}{l}0 \\
1 \\
2 \\
3\end{array}$ & $3 a, 3 b$ \\
\hline
\end{tabular}


There are two groups which are already choosen then both of them are given different treatment. After giving treatment in each class where experimental class I used TTW type and experimental class II used NHT type. Based on the purpose above, the design of this experimental research is Posttest Only group (Best, 1981 : 73). It is presented like the explanation below.

Table 2.

Research Design

\begin{tabular}{lcc}
\hline \multicolumn{1}{c}{ Class } & Treatment & Posttest \\
\hline Experiment 1 & $\mathrm{X}_{1}$ & $\mathrm{O}_{1}$ \\
\hline Experiment II & $\mathrm{X}_{2}$ & $\mathrm{O}_{2}$ \\
\hline Note: & $\mathrm{O}_{1}$ and $\mathrm{O}_{2}=$ Mathematical communication ability test, \\
$\mathrm{X}_{1}=$ Treatment uses TTW type, and \\
$\mathrm{X}_{2}=$ Treatment uses NHT type.
\end{tabular}

The procedure conducted in this research is consisted of several stages: 1) Preparation stage: In this stage, the determination of population and sample and preparation of creating RPP, teaching materials, and research instruments were done, 2) Stage of treatment giving: In this stage, TTW type is implemented in the experimental class 1 and NHT type is implemented in experimental class II, 3) Posttest stage: The mathematical communication ability test was done to find out the final grade and score of mathematical communication indicator of the students in the both of experimental class after being treated, 4) Stage of data analysis: In this stage, the data analysis was conducted using statistical method that compared the posttest result in the both of experimental class after the treatment, 5) Stage of hypothesis testing: In this stage, conclusion was made to reject or accept the results of hypotheses based on the results of data processing, 6) Stage of making conclusions: In this stage, the researchers made conclusion based on the results of hypothesis testing. Data analysis technique is a way to process the data so that the information from the research conducted can be presented. After the data had been obtained statistically, the data were analyzed by the following steps: (1) Calculating the mean, (2) Normality Test, (3) Homogeneous Test, and (4) Hypothesis Test. After that, the test is continued for knowing which better student's mathematical communication ability which taught by TTW type or by NHT type.

\section{RESULT AND DISCUSSION}

\section{Data Description}

After treatment is implemented in both of experimental class in the topic Rectangle and Square, the sample is 72 students, the research had been carried out by providing test in the form of essay to students of grade VII at SMP Negeri 1 Lubuk Pakam. All the results of tests that had been completed were collected to be analyzed.

Table 3.

Posttest Grade of Experiment Class I and Experimental Class II

\begin{tabular}{lcccccc}
\hline \multicolumn{1}{c}{ Class } & N & Minimum & Maximum & Mean & Std.Deviation & Variance \\
\hline Experiment 1 & 36 & 53.33 & 93.33 & 81.11 & 9.76 & 95.24 \\
\hline Experiment II & 36 & 46.67 & 100 & 75.93 & 13.17 & 173.40 \\
\hline
\end{tabular}

For knowing the difference of student's mathematical communication ability in both of experimental class deeply then score per indicator of mathematical communication ability needed. The complete explanation for each of indicator of mathematical communication ability where the indicators are (1) the ability of stating mathematical problem into mathematical model and solving it, (2) the ability of explaining mathematical problem into figure, and (3) the ability of explaining problem situations by own words and doing calculation available in test.

This following table shows the score of three indicators of mathematical communication ability test in both of experimental class. 
The Difference of Students' Mathematical Communication Ability Taught by Cooperative Learning Model Think Talk Write Type and ... (Meiva Marthaulina Lestari Siahaan, E. Elvis Napitupulu)

Table 4.

Mean of Mathematical Communication Ability Indicators

\begin{tabular}{cccc}
\hline Indicator & Experimental Class I & Experimental Class II & \multirow{2}{*}{ Ideal Score } \\
\cline { 1 - 3 } & TTW & NHT & 3.00 \\
\hline 1 & 2.22 & 2.20 & 3.00 \\
\hline 2 & 2.67 & 2.56 & 3.00 \\
\hline 3 & 2.30 & 1.82 & \\
\hline
\end{tabular}

Based on data of student's mathematical communication ability test score is founded that average score of student's mathematical communication ability who taught by cooperative learning model type TTW is higher than type NHT. It is also supported by the data score per indicator mathematical communication skills. The three indicators that there is improvement in the experimental class I or class taught by cooperative learning model of type TTW compared with type NHT. This may be due to differences in syntax learning of a given type of treatment cooperative learning model TTW type. Students are required to find their own nature extent and square and rectangular perimeter through existing activities in the SAS so that every student is not only memorize formulas but also understand what is in rectangular and square. Unlike the cooperative learning model of type NHT. The material here is given by the teacher and then students work on the problems questions relating to the material on the SAS. Thus, most students memorize formulas and properties of rectangles and squares.

1. Data Analysis

a. Data Normality Test

For knowing the data has normalized distribution or not in then it need to be done normality test. For the result of normality test completely can be seen like the table below.

Table 5.

Normality Test of Both of Experimental Class

One-Sample Kolmogorov-Smirnov Test

\begin{tabular}{|ll|r|}
\hline & & \multicolumn{1}{|c|}{ Result } \\
\hline Normal Parameters ${ }^{\mathrm{a}}$ & Mean & 72 \\
& Std. Deviation & 78.5181 \\
Most Extreme Differences & Absolute & $1.17998 \mathrm{E} 1$ \\
& Positive & .136 \\
& Negative & .103 \\
& & -.136 \\
Kolmogorov-Smirnov Z & & 1.151 \\
Asymp. Sig. (2-tailed) & & .141 \\
\hline
\end{tabular}

a. Test distribution is Normal.

Based on the result of normality test it is shown that the significance value of mathematical communication ability test data which is exist in row Asymp Sig (2-tailed) is 0.141 . This value is higher than 0.05 or the significant value $>\alpha$. It shows that mathematical communication ability test data in both of experimental class has normalized distribution.

b. Data Homogeneity Test

Homogeneity test whose purposed for knowing sample data comes from population whose homogenous variance or not. The complete result of homogeneity test can be seen from the table below. 
Table 6.

Homogeneity Test of Both of Experimental Class

\begin{tabular}{|c|c|c|c|c|c|}
\hline & & Levene Statistic & df1 & $\mathrm{df} 2$ & Sig. \\
\hline \multirow{4}{*}{$\begin{array}{l}\text { Mathemati } \\
\text { cal } \\
\text { Communic } \\
\text { ation } \\
\text { ability test }\end{array}$} & Based on Mean & 1.837 & 1 & 70 & .180 \\
\hline & Based on Median & 1.590 & 1 & 70 & .211 \\
\hline & $\begin{array}{l}\text { Based on Median and with } \\
\text { adjusted df }\end{array}$ & 1.590 & 1 & 60.903 & 212 \\
\hline & Based on trimmed mean & 1.783 & 1 & 70 & .186 \\
\hline
\end{tabular}

From the result of homogeneity test known that significance value of posttest data which is exist in the row based on mean is 0.180 . this value is higher than 0.05 or the significant value $>$ $\alpha$. . It shows that mathematical communication ability test data in both of experimental class is homogenous. It can be concluded that sample data represents an exist population.

c. The Hypothesis Test

The test is done on posttest data by comparing the difference average of posttest between students who taught by cooperative learning model type TTW with type NHT by One Sample T - Test is obtained the result like the table below.

Table 7.

The Result of T- Test

\begin{tabular}{|c|c|c|c|c|c|c|}
\hline & \multicolumn{6}{|c|}{ Test Value $=72$} \\
\hline & \multirow[b]{2}{*}{$\mathrm{t}$} & \multirow[b]{2}{*}{ df } & \multirow{2}{*}{$\begin{array}{l}\text { Sig. }(2- \\
\text { tailed) }\end{array}$} & \multirow{2}{*}{$\begin{array}{c}\text { Mean } \\
\text { Difference }\end{array}$} & \multicolumn{2}{|c|}{$\begin{array}{c}95 \% \text { Confidence Interval } \\
\text { of the Difference }\end{array}$} \\
\hline & & & & & Lower & Upper \\
\hline $\begin{array}{l}\text { Test of Mathematical } \\
\text { Communication } \\
\text { Ability }\end{array}$ & 4.687 & 71 & .000 & 6.51806 & 3.7452 & 9.2909 \\
\hline
\end{tabular}

Known the hypotheses in this research are :

$\mathrm{H}_{\mathrm{o}}$ : There is no difference of student's mathematical communication ability who taught by cooperative learning model type TTW with NHT

$\mathrm{H}_{\mathrm{a}}$ : There is difference of student's mathematical communication ability who taught by cooperative learning model type TTW with NHT

From the result of hypotheses test table above is obtained $t_{\text {calculated }}=4.687$ whereas $t_{\text {table }}=$ 1.667 so $t_{\text {calculated }}>t_{\text {table }}$ then $\mathrm{H}_{\mathrm{o}}$ is rejected and $\mathrm{H}_{\mathrm{a}}$ is accepted. So. it can be concluded that there is difference of student's mathematical communication ability who taught by cooperative learning model type TTW with NHT.

After that, the test is continued for knowing whether student's mathematical communication ability which taught by cooperative learning model type TTW is better than student's mathematical communication ability which taught by cooperative learning model type NHT by Independent Sample Test is obtained the result like the table below. 
Table 8.

The Result of Advance Hypotheses Test

\begin{tabular}{|c|c|c|c|c|c|c|c|c|c|c|}
\hline & \multicolumn{2}{|c|}{$\begin{array}{c}\text { Levene's } \\
\text { Test for } \\
\text { Equality of } \\
\text { Variances }\end{array}$} & \multicolumn{7}{|c|}{$\mathrm{t}$-test for Equality of Means } \\
\hline & & \multirow[b]{2}{*}{$\mathrm{F}$} & \multirow[b]{2}{*}{ Sig. } & \multirow[b]{2}{*}{$\mathrm{t}$} & \multirow[b]{2}{*}{ df } & \multirow{2}{*}{\begin{tabular}{|c|} 
Sig. \\
$(2-$ \\
tailed \\
) \\
\end{tabular}} & \multirow{2}{*}{$\begin{array}{c}\text { Mean } \\
\text { Difference }\end{array}$} & \multirow{2}{*}{$\begin{array}{l}\text { Std. Error } \\
\text { Difference }\end{array}$} & \multicolumn{2}{|c|}{$\begin{array}{c}\text { 95\% Confidence } \\
\text { Interval of the } \\
\text { Difference } \\
\end{array}$} \\
\hline & & & & & & & & & Lower & Upper \\
\hline Posttest & $\begin{array}{l}\text { Equal } \\
\text { variances } \\
\text { assumed }\end{array}$ & 1.837 & .180 & 1.898 & 70 & .062 & 5.18500 & 2.73162 & $\mid-.26304$ & 10.63304 \\
\hline & $\begin{array}{l}\text { Equal } \\
\text { variances } \\
\text { not assumed }\end{array}$ & & & 1.898 & 64.538 & .062 & 5.18500 & 2.73162 & $\mid-.27116$ & 10.64116 \\
\hline
\end{tabular}

Known the hypotheses for advance test are :

$\mathrm{H}_{\mathrm{o}}=$ The student's mathematical communication ability which taught by cooperative learning model type TTW is not better than student's mathematical communication ability which taught by cooperative learning model type NHT.

$\mathrm{H}_{\mathrm{a}}=$ The student's mathematical communication ability which taught by cooperative learning model type TTW is better than student's mathematical communication ability which taught by cooperative learning model type NHT.

Based on the table of advance hypotheses above is obtained $t_{\text {calculated }}=1.898$ whereas $t_{\text {table }}$ $=1.667$ so $t_{\text {calculated }}>t_{\text {table }}$ then $H_{o}$ is rejected and $H_{a}$ is accepted. So. it can be concluded that the student's mathematical communication ability which taught by cooperative learning model type TTW is better than student's mathematical communication ability which taught by cooperative learning model type NHT.

\section{Discussion}

From both learning models which were used in both experimental classes have steps that are possible to encourage acceleration in achieving student's mathematical communication. The steps in TTW can fulfill the indicator of student's mathematical communication ability in general. In Think phase, students read and did activities in SAS and make notes of individual readings, to be taken to the discussion forum. In this phase, students can explore themselves to answer the problems in SAS. The main purpose of this phase is achieved by encourage and force students to explain problem by their own word and stating mathematical problem into mathematical model yet explaining the figure, with the guidance from the teacher, even the student's answer is not perfect. At the Talk phase, students discuss the notes that they have made and unite their answer as one group. In this phase may happened assimilation because answers in one group are so various. In Write phase, the students write discussion result in SAS after that teacher explains about right answer. It may be possible to understanding accommodate the process since the students will modify and link their own cognitive between their answer and teacher's explanation. The students also ask if there is explanation that they have not understood yet. These can influence student's mathematical communication ability starts from their mathematical understanding and all aspects of communication like listening (to friend's and teacher's explanation), reading (reading the SAS), discussing (talk with friend), writing (write discussion result), and representing are satisfied. It makes factors of mathematical communication ability automatically satisfied like prior knowledge (think), reading, discussing, and writing ability and mathematical knowledge.

Cooperative learning model type NHT has steps head together which supports assimilation process also communication aspect in discussing and writing and answering step will support in representing as one of communication aspect. Prior knowledge of students do not appear in writing only orally but in whatever the form to apply the prior knowledge, it is helpful for students to build 
their further knowledge (Khaskan, 2016 : 49). The "head together" phase force students to remark what they think because there is number at every single student to be prepared for giving the answer. The drawback of this model is there is no phase that encourage students to think before they collaborate with their team. This phase is useful for students to be able to manage their mind before share it. Both models encourage students to do activities which stimulate their mathematical communication ability, because when students think about, respond to, discuss, elaborate, read, listen to, write or even discover mathematical concepts, at the same time; they do two related communication activities: (1) communicating to learn mathematics, this can be affect to encourage other students to learn mathematics, (2) learning mathematical communication, this affect to students themselves (Carpenter and Gorg, 2000).

The research result reinforces some studies done by Ul Husnah and Edy Surya (2017) that TTW type was effective for students' mathematical communication skills of grade VIII also the study from Tarigan (2017) stated that increase of students' mathematical reasoning ability was greater in the NHT compared to TPS (Think Pair Share) learning model. Overall, the result research is reinforced by relevant studies.

There are some constraints faced by researchers through direct observations by partners while conducting treatment in both classes. The observer monitors learning process through lesson plan. At the first meeting in both of experimental class found several problems. Constraints on the experimental class I (TTW) is when the discussion took place some students also seem silent and had not issued his opinion. In addition, students who did not pay attention when other students were presented the results of the group discussions. So that no group of students who responded to the presentation of the answer though the answer presented is wrong. The process of discussions and presentations as well exceeds the planned time so that at the first meeting until the conclusion of the discussion yet. Another constrain is found that at this stage tend to think these students are already discussing with other students so that little note was made relatively the same. Therefore Think and Talk stage is not too visible difference.

While the constraints on the experimental class II (NHT) which heads together on stage when most students only understand the matter in accordance with the numbers he had and about in addition to the number that he has denied. While on stage answering if the student has been presented with a certain number of answer he would pay less attention to the presentation of answers after that student numbers have not been active for a response to his answer.

\section{CONCLUSION AND SUGGESTION}

Based on the result of research and discussion can be concluded that there is difference of student's mathematical communication ability which taught by cooperative learning model TTW type with NHT type at SMP Negeri 1 Lubuk Pakam. The three indicators of mathematical communication ability at class which taught by TTW type is higher than class which taught by NHT type. For the indicator of the ability of stating mathematical problem into mathematical model and solving it, the students taught by TTW type have higher result than the student taught by NHT type. For the indicator of the ability of explaining mathematical problem into figure, the students taught by TTW type have higher results than the students taught NHT type. For the indicator of the ability of explaining problem situations by own words and doing calculation, students taught by TTW type has higher results than student taught by NHT type.

Mathematics teachers are suggested to use cooperative learning model type TTW or NHT as learning model alternative in improving student's mathematical communication ability. Based on communication aspect that will be achieved, cooperative learning model TTW type is more effective than cooperative learning NHT type because the syntaxes of cooperative learning model TTW type including all communication aspects. 
The Difference of Students' Mathematical Communication Ability Taught by Cooperative Learning

Model Think Talk Write Type and ... (Meiva Marthaulina Lestari Siahaan, E. Elvis Napitupulu)

\section{REFERENCES}

Ansari, B., (2012), Komunikasi Matematik dan Politik Suatu Perbandingan : Konsep dan Aplikasi, Banda Aceh, Pena.

Arends, R., (2008), Learning To Teach, Pustaka Pelajar, Yogyakarta.

Best, J.W., (1981), Research in Education, Prantice - Hall, USA.

Carpenter, J. \& Gorg, S. (2000). Principles and Standards for Mathematical School. Reston VA: National Council of Teachers of Mathematics.

Hudojo, H., (2005), Pengembangan Kurikulum dan Pembelajaran Matematika, Universitas Negeri Malang (UM Press), Malang.

Ishabu, S., (2013), Online Mathematics Module : The Improve Learning Results and Creativity Student To Lesson Operation Count Numbers Through Cooperative Learning Type NHT, Journal of Mathematics Education 3 : 2225 - 0522.

Khaskan K 2016 The Effectiveness of Using the 7E's Learning Cycle Strategy on the Immediate and Delayed Mathematics Achievement and the Longitudinal Impact of Learning among Preparatory Year Students at King Saud University (KSU). Journal of Education and Practice 7(36) 40-52.

NCTM, (1989), Curriculum and Evaluation Standards for School Mathematics, NCTM, USA.

NCTM, (2000), Principle and Standard for Mathematics, NCTM, USA.

Qohar, Abd., (2011), Online Mathematics Module : Mathematical Communication : What and How To Develop It in Mathematics Learning, Journal of Mathematics Education : 978 - 979 $16353-7-0$.

Tarigan, Flora Astyana Putri, Edy Surya, and Yusnadi. The Difference in Improving Students' Mathematics Understanding and Ability of Visual Thinking by Using Cooperative Learning Model types Think Pair Shared (TPS) and Number Head Together (NHT) At SDN Percobaan Medan, vol 7, pp 74-81, Dec. 2017

Ul Husnah, Nida and Edy Surya. The Effectiveness of Think Talk Write Learning Model in Improving Students' Mathematical Communication Skills at MTs Al Jami'yatul Washliyah Tembung, vol 34, pp. 1-12, Juli 2017

Uno, H., (2011), Model Pembelajaran : Menciptakan Proses Belajar Mengajar Yang Efektif, Bumi Aksara, Jakarta.

Wichelt, L.,(2009), Communication : A Vital Skill of Mathematics, Paper of Research Project, University of Nebraska, Lincoln. 